\title{
小型無人機の動特性同定を目的とした風洞内係留飛行試験法*1 Captive Flight Testing in a Wind Tunnel for Identification of Dynamic Characteristics of a Small-Sized UAV
}

\author{
深 見 浩 司 ${ }^{* 2} \cdot$ 東野伸一郎 ${ }^{* 2} \cdot$ 桜 井 晃 ${ }^{* 2}$ \\ Koji Fukami, Shin-ichiro Higashino and Akira Sakurai
}

\begin{abstract}
Key Words : Captive Flight, Wind Tunnel, Aerodynamic Characteristics, Unmanned Aerial Vehicle, Static Stability, Natural Mode
\end{abstract}

\begin{abstract}
This paper presents the concept of dynamic wind tunnel testing using captive flight method, in which the airplane is supported by three elastic lines mainly in the vertical direction, and given oscillatory motions by an external actuator. This experimental method is designed for the aerodynamic parameter estimation. Longitudinal and lateral dynamic tests are carried out sweeping driving frequency, and every mode except surging motion, of which damping is weak, was excited. Aerodynamic parameters estimated from flight data showed good accordance with reference data. This experimental method has the advantages of the experimental simplicity, quite small aerodynamic interference, stable flight and the capability of the excitation of motion necessary for the estimation.
\end{abstract}

$$
\begin{aligned}
& \text { 記 } \\
& \text { 号 } \\
& a_{x}, a_{y}, a_{z}: \text { 加速度 } \\
& b: \text { 主翼翼幅 } \\
& \bar{c}: \text { 主翼平均空力翼弦, ライン減衰係数 } \\
& C_{D}, C_{Y}, C_{L} \text { : 抗力係数, 横力係数, 揚力係数 } \\
& C_{l}, C_{m}, C_{n} \text { : ローリングモーメント係数 , ピッチン } \\
& \text { グモーメント係数, ヨーイングモーメ } \\
& \text { ント係数 } \\
& C_{m}^{A}: \text { 空カピッチングモーメント係数 } \\
& C_{m}^{T}: \text { 張カピッチングモーメント係数 } \\
& C_{T}: \text { 張力係数 } \\
& C_{W}: \text { 重力係数 } \\
& F_{D X}, F_{D Z} \text { : 下方ラインのロードセル出力 (風洞軸 } \\
& x, z \text { 方向 }) \\
& F_{R Y}, F_{R Z} \text { : 右方ラインのロードセル出力 (風洞軸 } \\
& y, z \text { 方向 ) } \\
& F_{L Y}, F_{L Z} \text { : 左方ラインのロードセル出力 (風洞軸 } \\
& y, z \text { 方向 ) } \\
& h_{c g X}, h_{c g Z} \text { : 重心点の無次元座標（機体軸 }-x,-z \\
& \text { 方向 ) } \\
& h_{n X}, h_{n Z} \text { : 中正点の無次元座標（機体軸 }-x,-z \\
& \text { 方向 ) } \\
& h_{t X}, h_{t Z} \text { : 係留点の無次元座標（機体軸 }-x,-z \\
& \text { 方向 ) } \\
& \bar{h}_{t X}, \bar{h}_{t Z} \text { : 係留中心の無次元座標 (機体軸 }-x,-z
\end{aligned}
$$

\footnotetext{
*1 (C) 2004 日本航空宇宙学会

平成 15 年 6 月 18 日原稿受理

$* 2$ 九州大学工学府航空宇宙工学専攻
}

\author{
方向） \\ $I_{x x}, I_{y y}, I_{z z}, I_{z x}:$ 慣性能率 , 慣性乗積 \\ $k:$ ラインの弾性係数 \\ $m:$ 機体質量 \\ $p, q, r$ : 角速度 \\ $S:$ 主翼面積 \\ $V:$ 風洞気流風速 \\ $\alpha, \beta$ : 迎角，横滑り角 \\ $\delta e$ : 昇降舵角 \\ $\phi, \theta, \psi$ : 姿勢角 \\ $\theta_{T}:$ ライン傾角
}

1. 緒言

近年，無人飛行機 (Unmanned Aerial Vehicle:UAV) の 研究開発か盛んになっており，観測，通信，軍事など樣々な分 野で応用か期待されている.無人機の最大の利点はパイロッ 卜の人命とコストがかからないこと，光してパイロットを意 識せずに自由に設計できることである.ナノテクノロジーや 微小機械システム (Micro Electro Mechanical Systems : MEMS) の分野の技術革新は著しく, 米国防総省高度研究 計画局 (Defense Advanced Research Projects Agency: DARPA）は 1990 年代より超小型無人飛行機 (Micro Air Vehicle:MAV) の研究開発に着手している.MAV の翼幅は $15 \sim 20 \mathrm{~cm}$, 重量は 10〜100 g 以下, 飛行速度は $20 \mathrm{~m} / \mathrm{sec}$ 前後の飛翔体とされる.こうした無人機の小型化と軽量化 に伴う飛行レイノルズ数の低下, 操舵応答の敏捷化, また 無人機に多く見られる奇抜な空力形態は空力性能に関する 理論的な推算をより困難なものにしている. 本研究では光 のような小型無人機の空力特性の推定を目的とした風洞内 
飛行試験法を提案する . 狙いは , シンプルで機体の加工を 必要とせずに良質の飛行データを得ることである．

風洞試験による航空機の動特性の測定は, 回転軸をもつ スティングを用いた定常回転法, 自由振動法, 強制振動法 などの方法か実施されてきた ${ }^{1,2)}$. これは支柱支持による通 常の静的な風洞試験を動的試験に応用したものであり，い ずれもスティングを介して模型を回転または振動させ，光 れに伴う空気力と運動の履歴から空力特性を推定するもの である .しかしながら，模型に運動を励起させるための高 い岡性が要求されること, 及び内装天秤による機構の複雑 さから, 動的試験に使用されるスティングはスケールが大 きく複雑な構造になりやすい, 光の結果, 通常の静的試験 よりも推定が困難な空力干涉の問題, 及び模型の空気力が スティングのダイナミクスに埋もれる可能性があった .

一方, 風洞内飛行試験に関してもこれまでにもすでに $\mathrm{NASA}^{3)}, \mathrm{NAL}^{4)}$ において数例の研究が行われている. 光 の多くは模型を前後方向 (気流方向) に，細い弾性のある ラインによって拘束し, 操舵入力によって運動を励起させ るものであった .このような係留飛行試験は, 大きな支持 装置を用いないため空力干渉の影響が小さ，またスティ ングの慣性力などの影響が存在しないが, 飛行の安定性と 運動の励起が大きな課題である . 前後方向の拘束は, 上下， 左右の並進運動に関して減衰か溺くなりやすく, 空力特性 の取得を目的とした動的試験を行う際には，必要に忍じて 制御系を作動させなければならないこと，及び操舵入力に よって発生した運動は操舵入力と状態变数の間に強い相関 関係が発生しやすいために同定解析が難しくなりやすいと いう問題5)があった .

筆者らか提案する風洞内係留飛行は第 1 図に示すような 方式をとっている. 飛行機は 3 本のラインによって主に垂 直方向に拘束され，1 本のラインは機軸上の点から下方へ， 残りの 2 本のラインは左右の翼端から横斜め上方へと拘束 する. 空力特性の推定に必要な運動を発生させる手段とし ては操舵入力を用いずに，機体を拘束しているラインを外 部モータによって駆動し，系を加振する方式をとった .

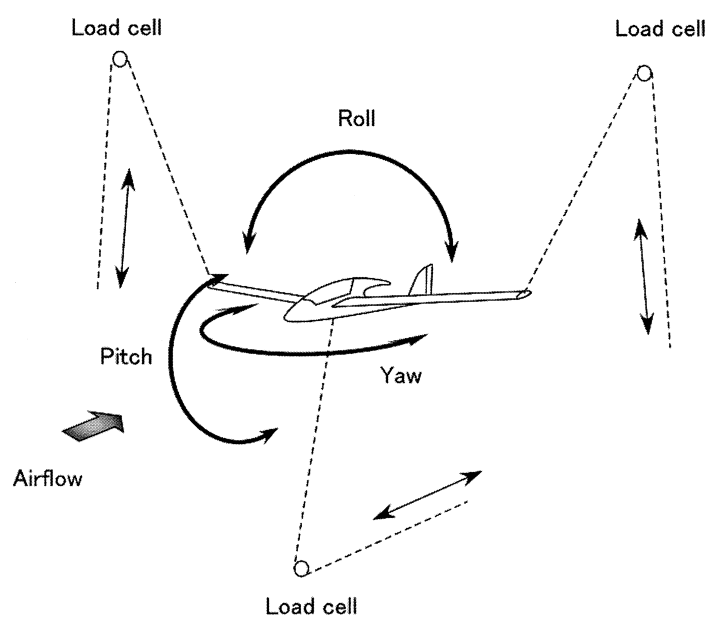

第1図 係留飛行の概略図
本稿では，風洞内係留飛行試験に関して，係留飛行の特 性と動的試験の方法について論じ，次いで，動的試験の測 定結果と解析結果について報告する．

\section{2. 係留飛行の安定性}

2.1 静安定 一般に, 迎角静安定の条件は $\mathrm{d} C_{m} / \mathrm{d} C_{L}<$ 0 であり, 自由飛行では, 重心が中正点よりも前方に位置 することが必要である.一方, 係留飛行では重心と中正点 の位置関係は迎角静安定に全く無関係であり，係留点（係 留索が機体に取付けられている点) が中正点よりも前方に 位置することか唯一の条件である．証明を以下に記す．

係留飛行の模式図を第 2 図に示す. 係留飛行では空気力 の他にラインカが復元に寄与し, 機体にかかる全モーメン 卜係数は以下のように表される .

$$
C_{m}=C_{m}^{A}+C_{m}^{T}
$$

迎角が十分小さいとき，空気力モーメントは，

$$
C_{m}^{A}=C_{m 0}-C_{L}\left(h_{n X}-h_{c g X}\right)+C_{D}\left(h_{n Z}-h_{c g Z}\right)
$$

$$
\begin{aligned}
& \text { ラインカモーメントは } \\
& \qquad \begin{aligned}
C_{m}^{T}= & \sum\left[C_{T} \sin \theta_{T}\left(h_{t X}-h_{c g X}\right)\right. \\
& \left.-C_{T} \cos \theta_{T}\left(h_{t Z}-h_{c g Z}\right)\right]
\end{aligned}
\end{aligned}
$$

と表される . ( $\Sigma$ は複数のラインによる拘束を想定してい る .) ところで, 係留飛行の並進運動に関する釣合式は

$$
\begin{aligned}
& \sum C_{T} \sin \theta_{T}=C_{L}-C_{W} \\
& \sum C_{T} \cos \theta_{T}=C_{D}
\end{aligned}
$$

と表され，式 (4)，(5) を式 (3) に代入すると，

$$
\begin{aligned}
C_{m}^{T}= & \left(C_{L}-C_{W}\right) \times \frac{\sum C_{T} \sin \theta_{T}\left(h_{t X}-h_{c g X}\right)}{\sum C_{T} \sin \theta_{T}} \\
& -C_{D} \times \frac{\sum C_{T} \cos \theta_{T}\left(h_{t Z}-h_{c g Z}\right)}{\sum C_{T} \cos \theta_{T}}
\end{aligned}
$$

となる.ここで， $\bar{h}_{t X}, \bar{h}_{t Z}$ (張力中心と呼ぶ）を

$$
\bar{h}_{t X}=\frac{\sum C_{T} \sin \theta_{T} h_{t X}}{\sum C_{T} \sin \theta_{T}}, \quad \bar{h}_{t Z}=\frac{\sum C_{T} \cos \theta_{T} h_{t Z}}{\sum C_{T} \cos \theta_{T}}
$$

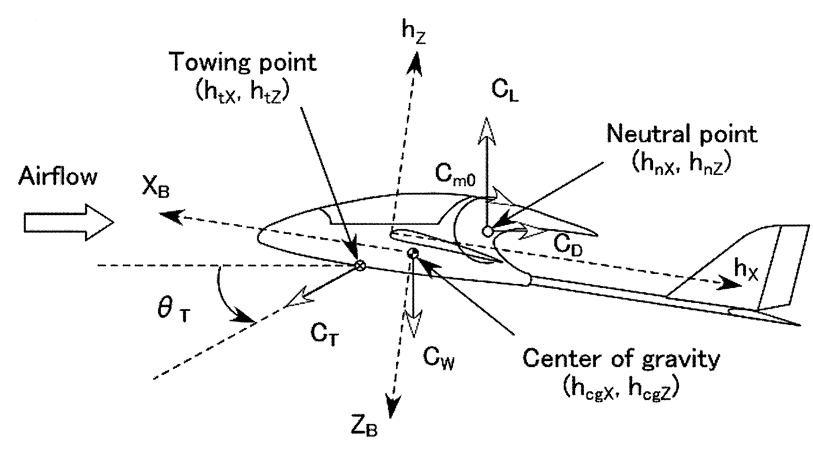

第 2 図 静安定の説明図 


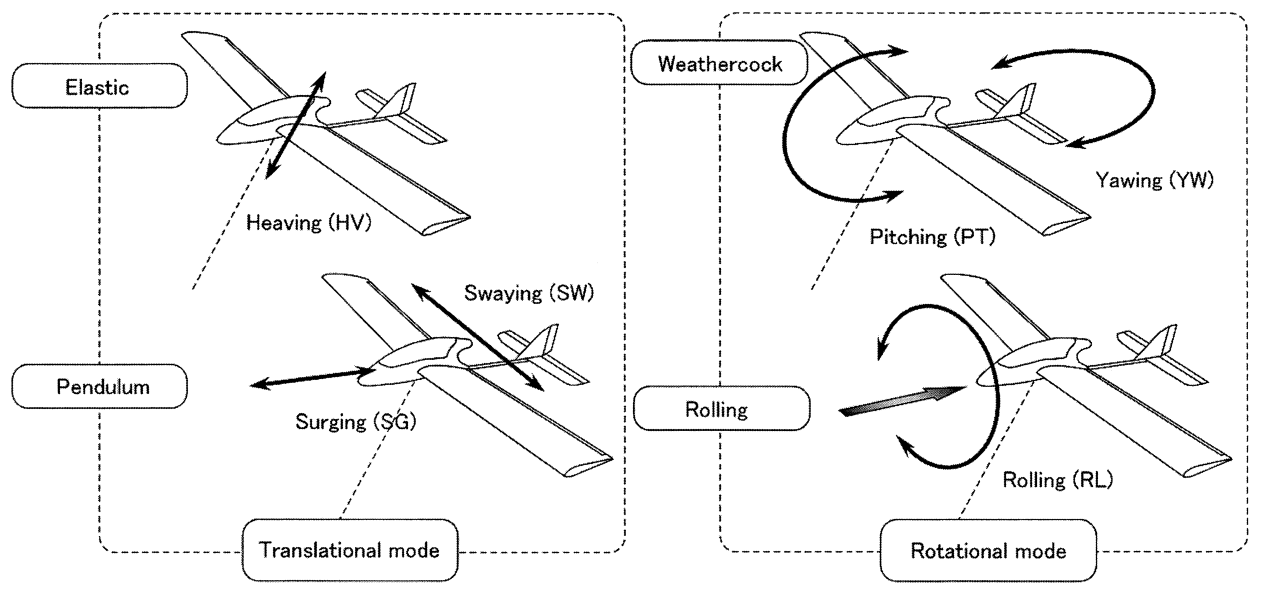

第3図 係留飛行の固有モード

と定義すると，式 (6) は以下のように表される .

$$
\begin{aligned}
C_{m}^{T}= & -C_{W}\left(\bar{h}_{t X}-h_{c g X}\right)+C_{L}\left(\bar{h}_{t X}-h_{c g X}\right) \\
& -C_{D}\left(\bar{h}_{t Z}-h_{c g Z}\right)
\end{aligned}
$$

式 (2)，(8)の和をとることにより，式 (1) は

$$
\begin{aligned}
C_{m}= & C_{m 0}-C_{W}\left(\bar{h}_{t X}-h_{c g X}\right)-C_{L}\left(h_{n X}-\bar{h}_{t X}\right) \\
& +C_{D}\left(h_{n Z}-\bar{h}_{t Z}\right)
\end{aligned}
$$

となる. 重心 $h_{c g}$ に関する項が全て打ち消されていること がわかる $. \mathrm{d} C_{m} / \mathrm{d} C_{L}$ は

$$
\begin{aligned}
\frac{\mathrm{d} C_{m}}{\mathrm{~d} C_{L}} & =-\left(h_{n X}-\bar{h}_{t X}\right)+\frac{\partial C_{D}}{\partial C_{L}}\left(h_{n Z}-\bar{h}_{t Z}\right) \\
& \cong-\left(h_{n X}-\bar{h}_{t X}\right)
\end{aligned}
$$

となり，静安定が成り立つためには $\bar{h}_{t X}<h_{n X}$ ，すなわ ち張力中心が中正点よりも前方に位置しなければならない． 張力中心は, 係留点位置と釣合状態のライン力係数, ライ ン傾角から決まるパラメータであり，ラインが 1 本のとき 張力中心は係留点と等しくなる.

風洞模型は必ずしも重心を中正点より前方に位置させる ことはできない．しかし，自由飛行における静安定条件が 満たされていなくとも，機体の拘束を前述の点に注意して 行えば静安定の確保は可能であり，係留飛行による風洞試 験を実施することができる .

2.2 動安定 係留飛行はラインによる拘束力が復元力 として作用するため, 本質的に自由飛行とは異なる状態に ある . 係留飛行の固有運動の模式図を第 3 図に示す．また， 固有運動の極配置を自由飛行と対比して第 4,5 図に示す. 計算条件は後に示す実験条件と同一である．

まず，係留飛行の固有運動は並進運動と回転運動に分け られる.さらに, 並進運動はラインの伸縮運動と振子運動 に分けられる . 伸縮運動はラインの張力変化が復元力とし て働き, 一方, 振子運動はライン張力の方向変化が復元力 として働く，一般に振子運動の減衰は非常に弱く，仮に機 体を前後方向に拘束するならば上下及び左右の並進運動に

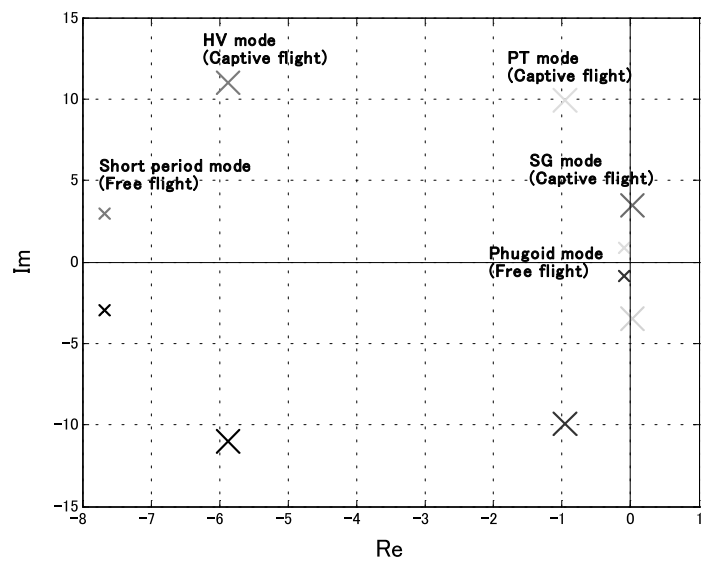

第 4 図＼cjkstart固有モードの極配置（縦）

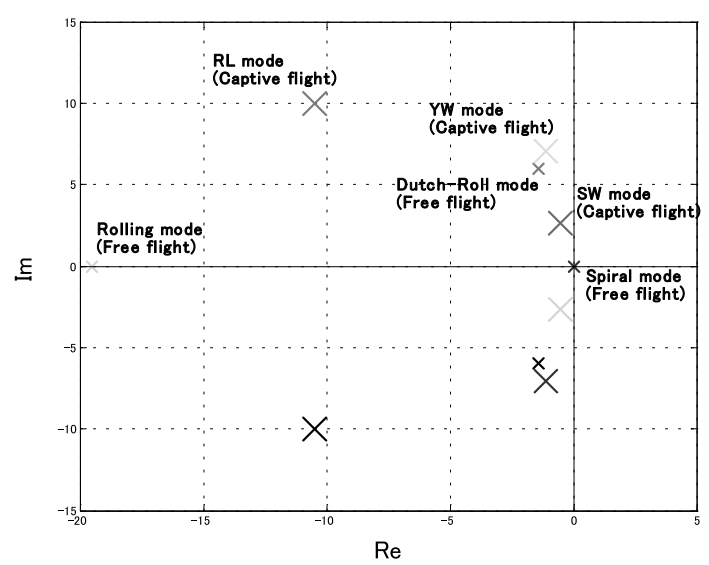

第 5 図 固有モードの極配置 (横)

関して不安定になりやすく，空力特性の取得を目的とした 動的試験を行う際には必要に応じて制御系を作動させなけ ればならない，一方，筆者らが提案する垂直係留方式は，上 下, 左右の並進運動に関して安定であり, 空力特性の取得 を目的とした運動を発生させやすい，減衰の弱い前後運動 に関しては, 弚の固有振動数が低いため, より高い振動数 で加振を行う動的試験では問題にはならない。

回転運動は係留点を回転中心とする風見安定の運動と機 


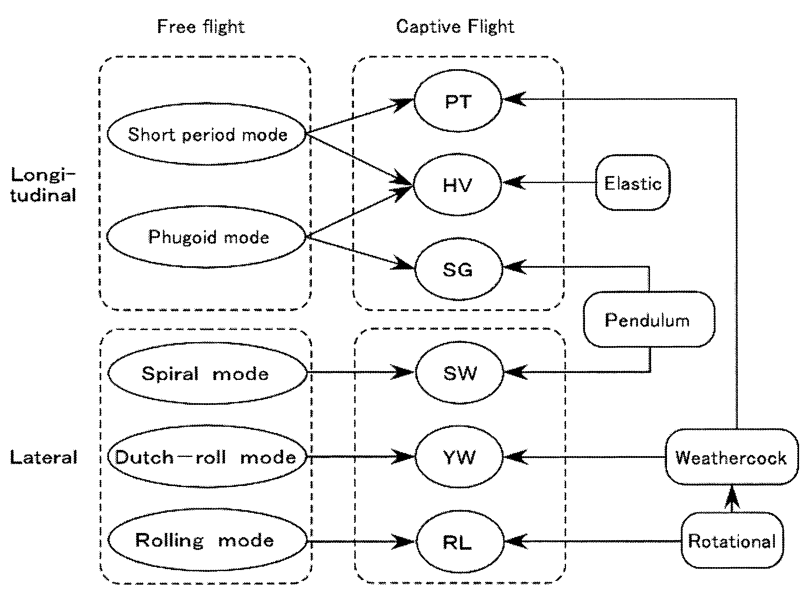

第 6 図 自由飛行と係留飛行の対応図

軸まわりのローリング運動に分けられる . 風見安定に起因 する運動，すなわちピッチングとヨーイングの運動は, 自 由飛行における短周期モードとダッチロールモードに相当 し, 弚の基本的な特性は大きくは変化しない, 一方, 係留 飛行ではローリングに対してもライン張力による復元モー メントが働くため, 他のモードと同樣に振動系となること が自由飛行との違いである. 自由飛行と係留飛行の固有運 動の関係図を第 6 図に示す .

前述したように, 何らかの方法て機体を拘束するとき，係 留飛行は本質的に自由飛行とは異なる状態にある．しかし ながら, 本研究の目的は空力特性の取得であり，自由飛行 のモ一ドを模擬する必要はないと考える，むしろ，係留飛 行の固有モードは全て振動系であり，加振周波数に応じて 全自由度の運動を励起させることができるため, 空力特性 の取得試験に有利であるといえる .

\section{3. 動的試験の方法}

動的試験は縦試験と横試験の 2 つに分けて行われる . 機 体の拘束方法はどちらも同一であるが，加振方法が異なっ ている. 動的試験の概略図を第 7,8 図に示す . 機体の拘束 にはナイロン製のライン $(\phi 0.74 \mathrm{~mm}$ ，破断強度 $20 \mathrm{kgf})$ を 使用し，風路外には弾性係数調整のためにゴム紐 $(\phi 5 \mathrm{~mm}$, 弾性係数 $10 \mathrm{~N} / \mathrm{m}^{2}$ ) カ挿入される. 加振装置はパルスモー タと回転ア一ムから構成され，風路外の床面に設置される． 回転アームの先に取付けられた 2 本のラインが滑車を経由 して機体に取付けられ，機体の運動を励起する．縦試験で は翼端ラインと下方ラインを交互に駆動させ，横試験では 下方ラインは固定し，左右の翼端ラインを交互に駆動する .

前後運動を除く全ての運動を励起させるために加振周波数 を推移させながら飛行データを取得する (第 9 図).縦試験は 初期速度 $1.05 \mathrm{~Hz}$, 最大速度 $1.63 \mathrm{~Hz}$ ，加速度 $\pm 0.23 \mathrm{~Hz} / \mathrm{sec}$ ， 測定時間は $50 \mathrm{sec}$ で実施され，上下並進とピッチングの連 成運動を励起する。横試験は初期速度 $0.93 \mathrm{~Hz}$, 最大速度 $2.33 \mathrm{~Hz}$, 加速度 $\pm 0.23 \mathrm{~Hz} / \mathrm{sec}$, 測定時間は $120 \mathrm{sec}$ で実 施され，左右並進，ヨーイング，ローリングのモードを励 起する。

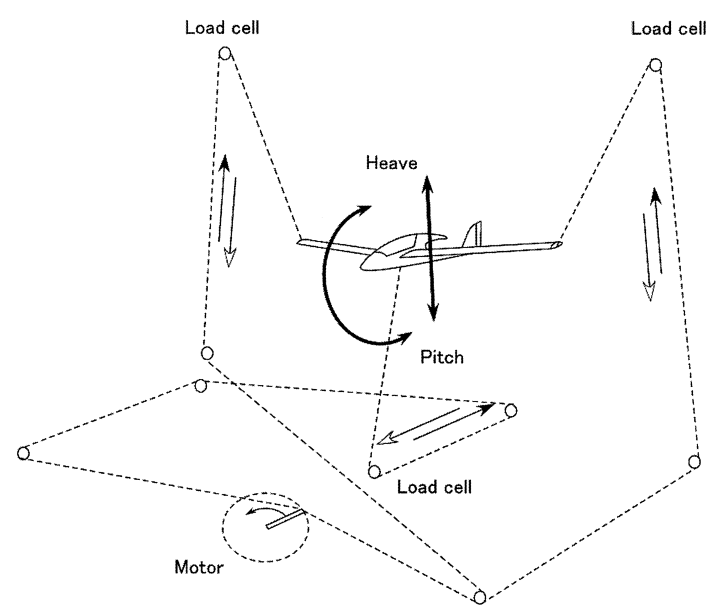

第 7 図 縦試験の概略図

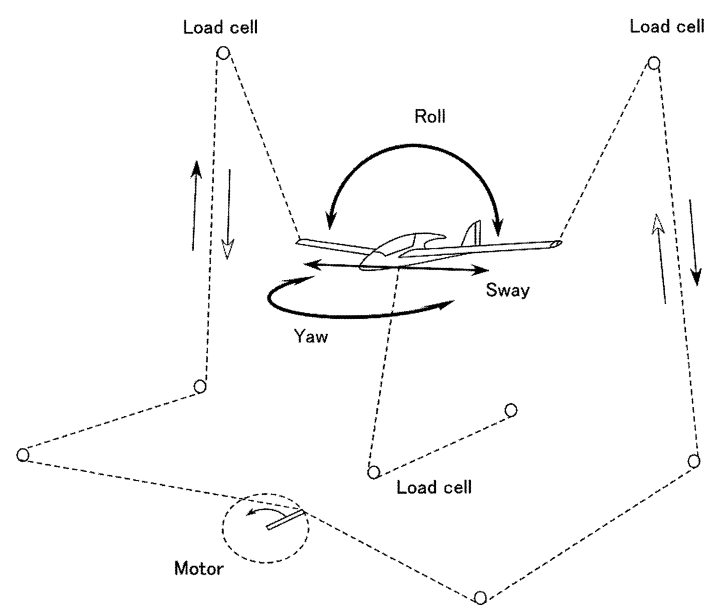

第 8 図 横試験の概略図

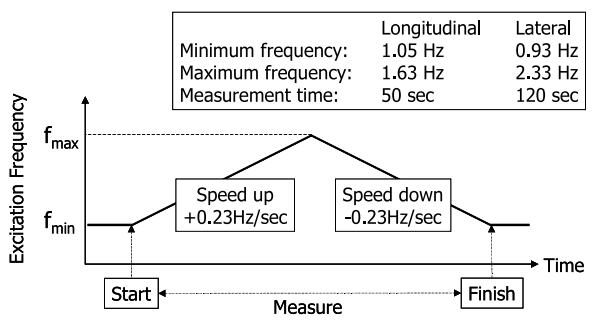

第 9 図＼cjkstart周波数スイーブ試験

計測システムを第 10 図に示す.機体には迎角/横滑り角 計, 加速度/角速度計, 及び $\mathrm{AD}$ 変換と通信バスをもつマイ コンか搭載され，機上で得られたデータはバスを介して風 洞側のマイコンに送信される、気流風速は風路に設置され たピトー静圧管によって，ライン張力は風路外に設置され たロードセルによって測定される．ラインがモータによっ て駆動されるため, ロードセルの着力点は滑車構造になっ ている.気流風速とロードセル出力は風洞側のマイコンで 処理され，機上データとともにシリアル通信によって PC

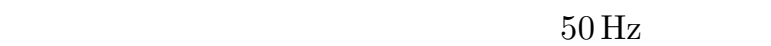

測定データの処理の流れを第 11 図に示す . 機体の姿勢角 
は加速度と角速度の出力から推定される ${ }^{6)}$. また , 各ロード セルは 2 軸方向の力を測定し , ライン張力の大きさとライ ンの傾角が計算される . 慣性モーメントは別試験で空気の 付加慣性モーメントを含んだ量が測定されている7) . 加速 度, 角速度出力から慣性力が, ロードセルからラインカが 求められ，機体の運動方程式から空気力が算出される.動 的試験に使用した機体の諸元を第 1 表に，実験条件を第 2 表に示す。

\section{4. 測 定 結 果}

動的試験の樣子と得られた測定データに関して , 縦試験

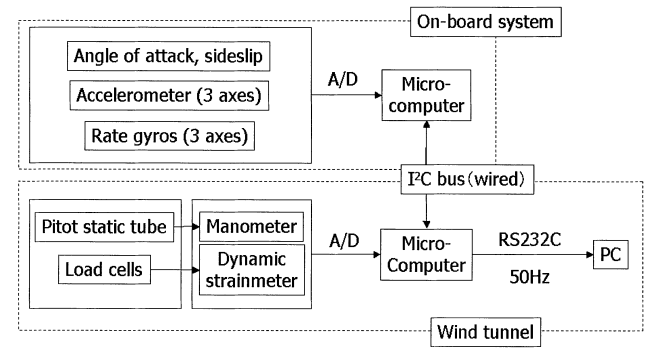

第 10 図計測システム
の結果を第 12,13 図に,横試験の結果を第 14,15 図に示 す. 縦試験，横試験ともに角速度が $100 \mathrm{deg} / \mathrm{sec}$ 以上の激 しい運動が発生しているにもかかわらず，正確に縦と横の 運動が分離している.

縦試験では $a_{Z}, q, \alpha, \theta$ か変動し, 上下振動とピッチン グが連成した運動が励起される．一方，横試験ではおもに $a_{y}, p, r, \beta, \phi, \psi$ が変動し，加振周波数を高くするとと もに左右並進モード, ヨーイングモード，ローリングモー ドの順に励起される.第 14 図上段は加振周波数 $1.63 \mathrm{~Hz}$ 時 の樣子であり，ヨーイングモードが励起されている．この とき，ヨーイング角速度とローリング角速度は $90 \mathrm{deg}$ だけ 位相がずれて振動しており，翼端の動きは側面から見ると 楕円状の奇跡を描いている.ヨーイングモード付近では加 振周波数の変化に忍じて変数間の位相差が大きく変化する 領域である . 加振周波数が $1.63 \mathrm{~Hz}$ よりも速くなると，急 速にヨーイング角速度の振幅が小さくなっていく.第 14 図 下段は加振周波数が $2.33 \mathrm{~Hz}$ 時の樣子であり，ローリング 角速度のみが激しく振動しているのがわかる . 操舵入力で は得られない高周波領域での大きな振幅の運動が本方式で は得られている.また, 縦試験, 横試験ともに加振周波数 の増速区間と減速区間の波形にヒステリシスはなく，加振 試験の再現性も確かめられた .

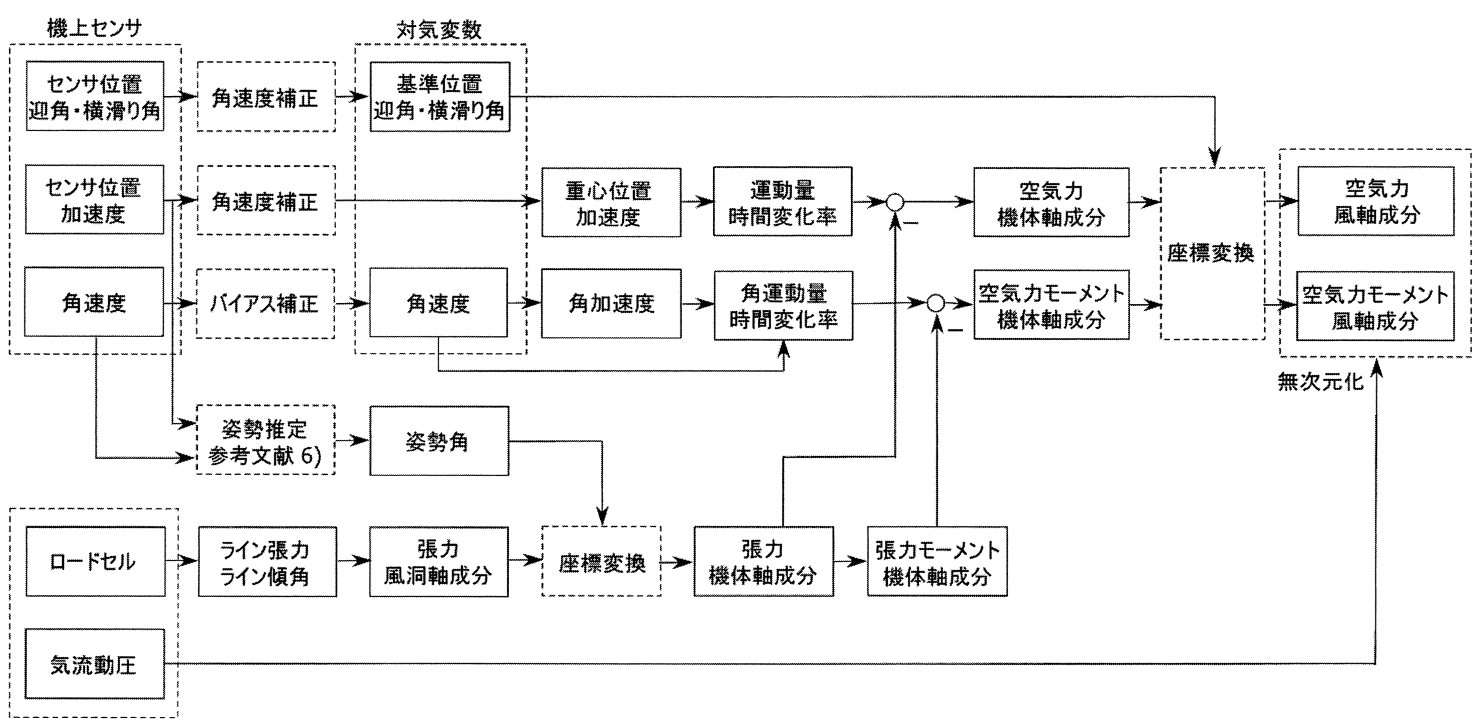

第11図 飛行データ処理の流れ図

第 1 表 機体諸元

\begin{tabular}{llcl}
\hline & Symbols & Values & Units \\
\hline Mass & $m$ & 1.395 & $\mathrm{~kg}$ \\
Moments of inertia & $I_{x x}$ & 0.059 & $\mathrm{kgm}^{2}$ \\
& $I_{y y}$ & 0.114 & $\mathrm{kgm}^{2}$ \\
& $I_{z z}$ & 0.165 & $\mathrm{kgm}^{2}$ \\
Product of inertia & $I_{x z}$ & 0.008 & $\mathrm{kgm}^{2}$ \\
Wing area & $S$ & 0.310 & $\mathrm{~m}^{2}$ \\
Chord length & MAC & 0.228 & $\mathrm{~m}$ \\
Wing span & $b$ & 1.360 & $\mathrm{~m}$ \\
CG position & $h_{c g X}$ & 87.0 & $\%$ \\
& $h_{c g Y}$ & 0.0 & $\%$ \\
& $h_{c g Z}$ & 0.0 & $\%$ \\
\hline
\end{tabular}

第 2 表 実験条件

\begin{tabular}{ccrrrl}
\hline & \multirow{2}{*}{ Symbols } & \multicolumn{3}{c}{ Lines } & \multirow{2}{*}{ Units } \\
\cline { 3 - 5 } & & Down & Right & Left & \\
\hline Position of towing & $h_{t X}$ & 26.3 & 26.3 & 26.3 & $\%$ \\
points & $h_{t Y}$ & 0.0 & 100.0 & -100.0 & $\%$ \\
& $h_{t Z}$ & -21.6 & 39.4 & 39.4 & $\%$ \\
Elastic coefficient & $k$ & 200.0 & 20.0 & 20.0 & $\mathrm{~N} / \mathrm{m}$ \\
Damping coefficient & $c$ & 0.52 & 0.52 & 0.52 & $\mathrm{~N} /(\mathrm{m} / \mathrm{sec})$ \\
\hline
\end{tabular}



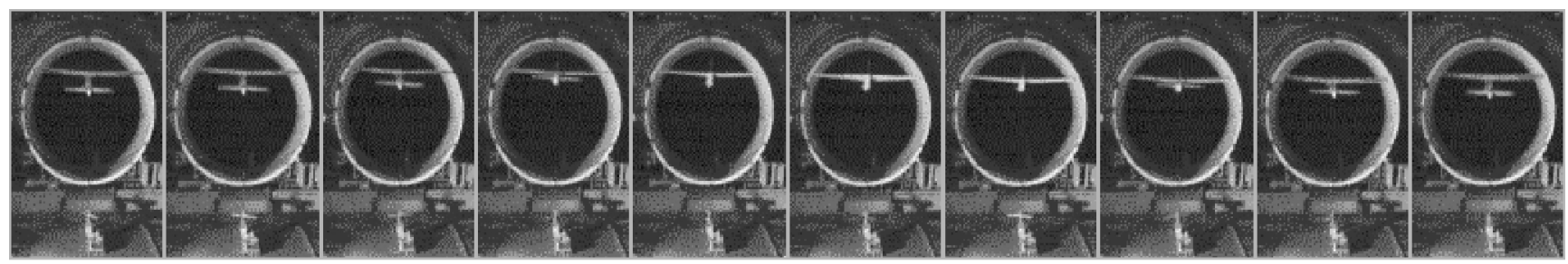

第 12 図 (縦) 動的試験の樣子 (加振周波数 $1.63 \mathrm{~Hz}$ )

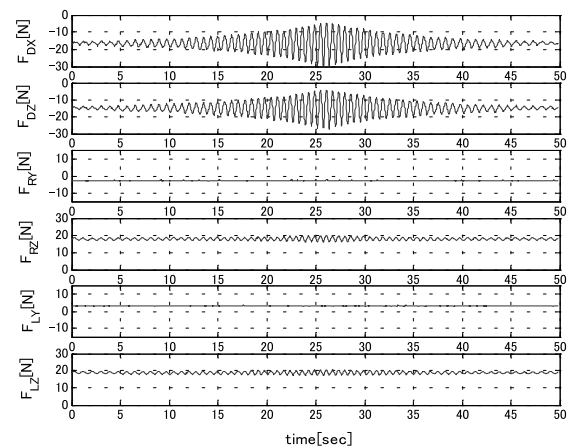

(a) ロードセル出力

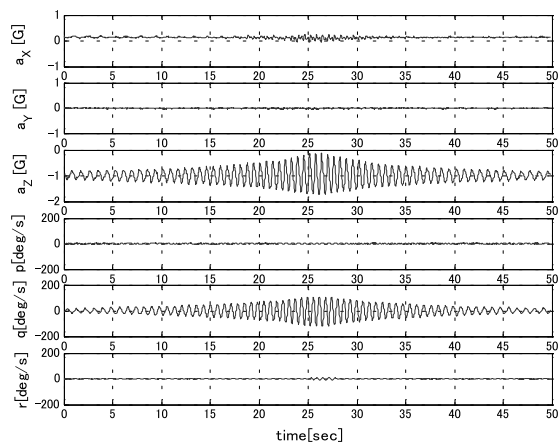

(b) 加速度 $\cdot$ 角速度

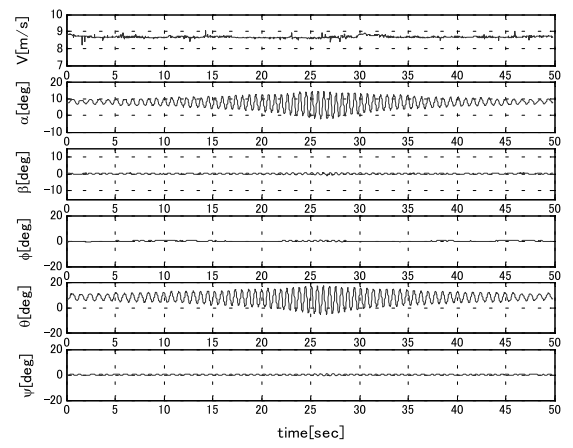

(c) 気流風速 $\cdot$ 迎角 $\cdot$ 横滑り角 $\cdot$ 姿勢角

第13図 (縦) 測定データ
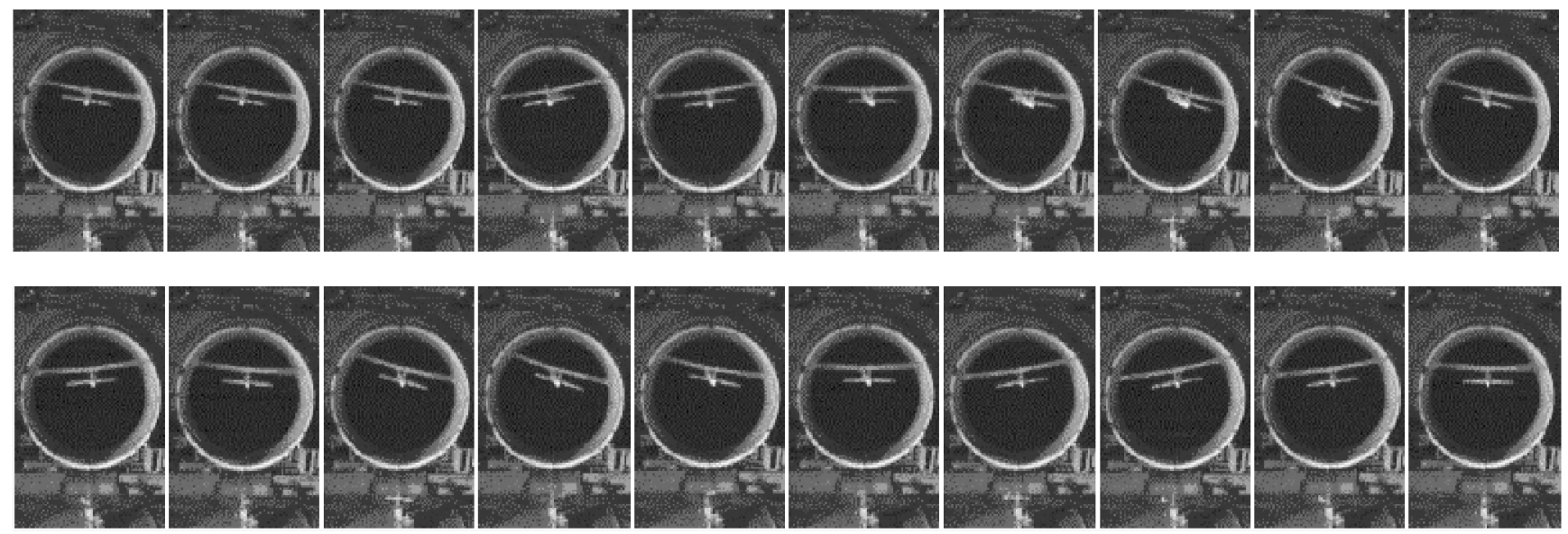

第 14 図 (横) 動的試験の樣子 (上段 : ヨーイングモード) (加振周波数 $1.63 \mathrm{~Hz}$ ) (下段 : ローリングモード) (加振周波数 $2.33 \mathrm{~Hz}$ )

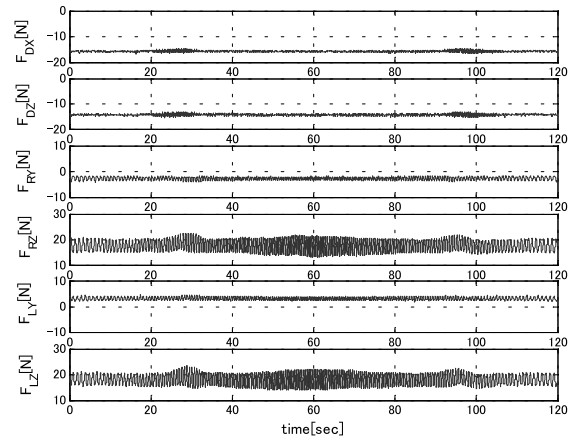

(a) ロードセル出力

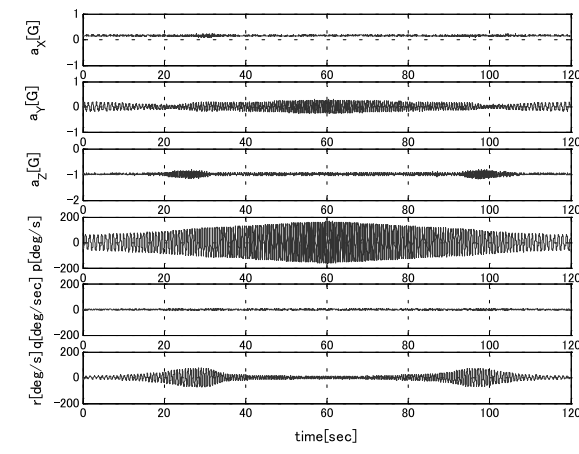

(b) 加速度 $\cdot$ 角速度

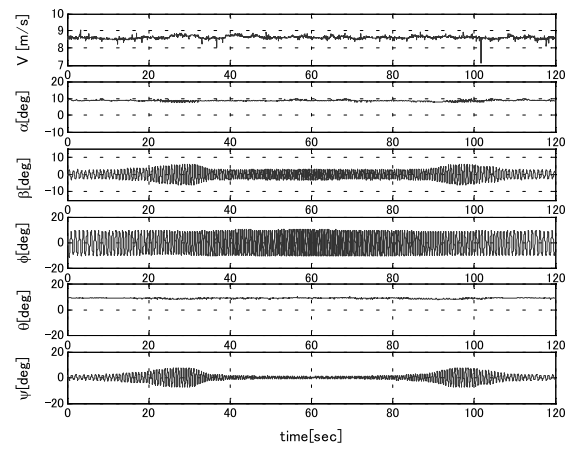

(c) 気流風速 $\cdot$ 迎角 $\cdot$ 横滑り角・姿勢角

第 15 図 (横) 測定データ

\section{5. 解析と考察}

小型無人機は速い応答特性をもち, 弚の固有振動数は空 気力の非定常性を無視できない領域にある. 本研究で使用
した試験機は自由飛行における短周期モードの固有振動数 は $1.5 \mathrm{~Hz}$ 程度であり, 無次元振動数は 0.1 を越える. 動的 試験での加振周波数の無次元值は縦試験では $0.08 \sim 0.13$, 横試験では $0.07 〜 0.20$ である。 

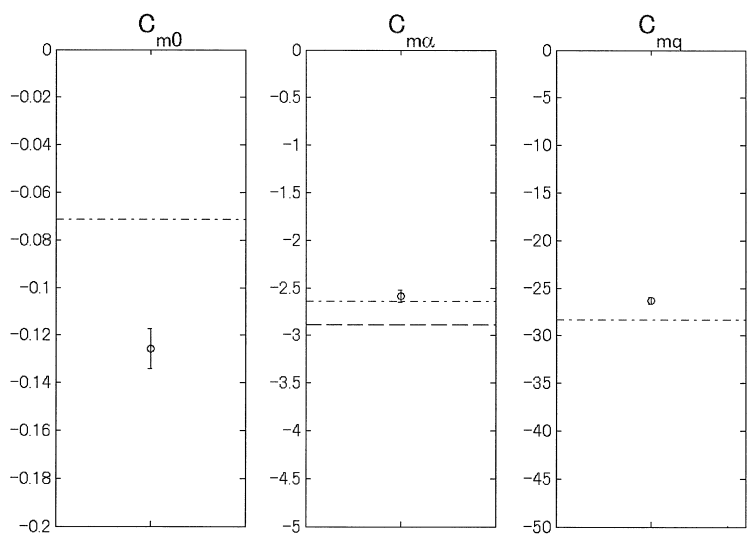

第 16 図 ピッチングモーメント係数に関するパラメータ推定結果
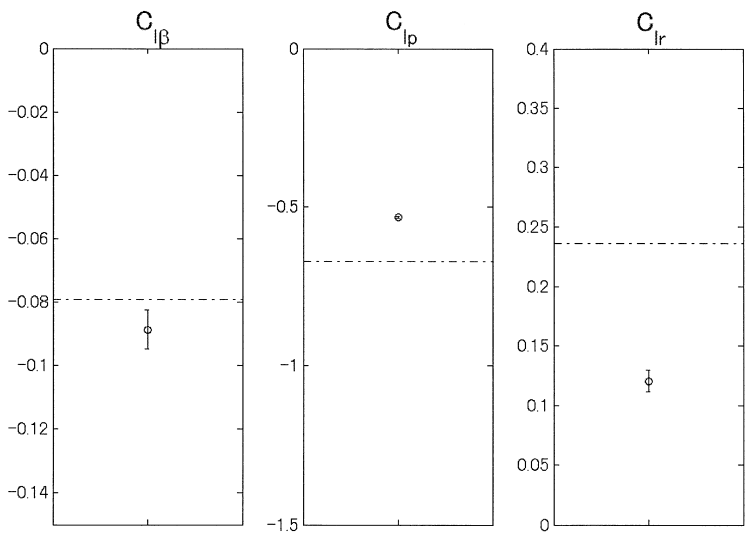

第17図 ローリングモーメント係数に関するパラメータ推定結果

空気力の非定常性を考慮した空力伝達関数モデルによる 解析を行う前の予備解析として, 準定常仮定に基づく空力 モデルで解析を行い，本試験法の妥当性を検証する．空力 モデルを次式のように仮定する．

縦 $\left\{\begin{array}{l}C_{L}=C_{L 0}+C_{L \alpha} \alpha+\left(C_{L q}+C_{L \dot{\alpha}}\right)(\bar{c} q / 2 V) \\ C_{D}=C_{D 0}+\kappa C_{L}{ }^{2} \\ C_{m}=C_{m 0}+C_{m \alpha} \alpha+\left(C_{m q}+C_{m \dot{\alpha}}\right)(\bar{c} q / 2 V)\end{array}\right.$

横 $\left\{\begin{array}{l}C_{Y}=C_{Y \beta} \beta+C_{Y p}(b p / 2 V)+C_{Y r}(b r / 2 V) \\ C_{l}=C_{l \beta} \beta+C_{l p}(b p / 2 V)+C_{l r}(b r / 2 V) \\ C_{n}=C_{n \beta} \beta+C_{n p}(b p / 2 V)+C_{n r}(b r / 2 V)\end{array}\right.$

動的風洞試験の目的は, 式 (11)，(12)の右辺の空力パラ メータの值を取得することである. 左辺の空力係数は取得 された飛行データから第 11 図の手順によって算出し,最小 二乗法によって空力パラメータの推定值を求める.第 16 18 図に空気力モーメントに関する推定結果を, 第 19〜21 図に空気力に関する推定結果を示す．○印はパラメータの 推定値を示し，縦線は $95 \%$ 信頼区間を示している. 図中に は, $\mathrm{DATCOM}^{8)}$ の方法によって求めた参照值 (一点鎖線)， 及ひ静的な風洞試験結果 (破線) も示している. 動特性に 大きな影響を及ぼす $C_{m q}, C_{l p}, C_{n r}$ に関して比較的良い
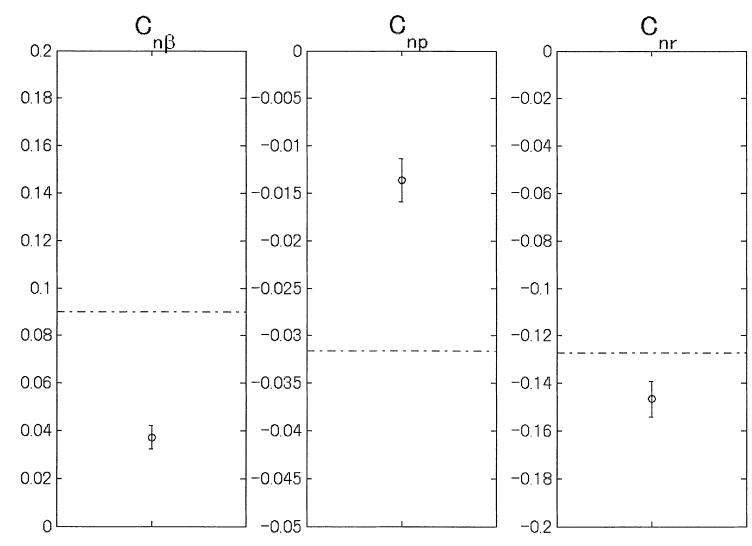

第18 図 ヨーイングモーメント係数に関するパラメータ推定結果
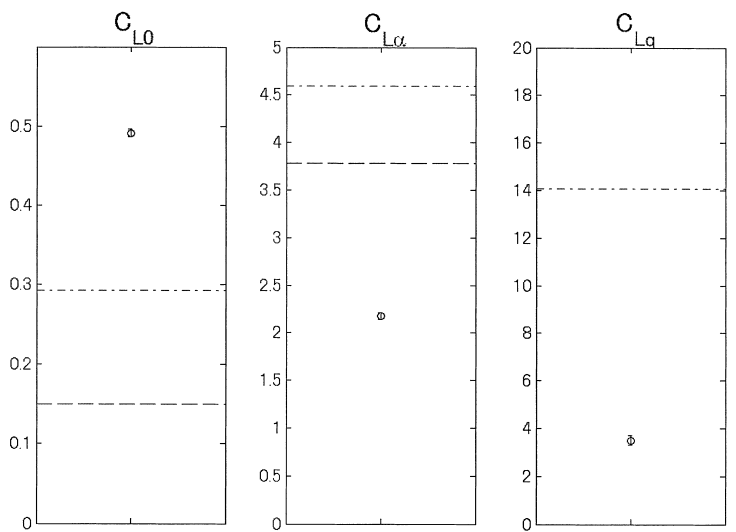

第19図 揚力係数に関するパラメータ推定結果
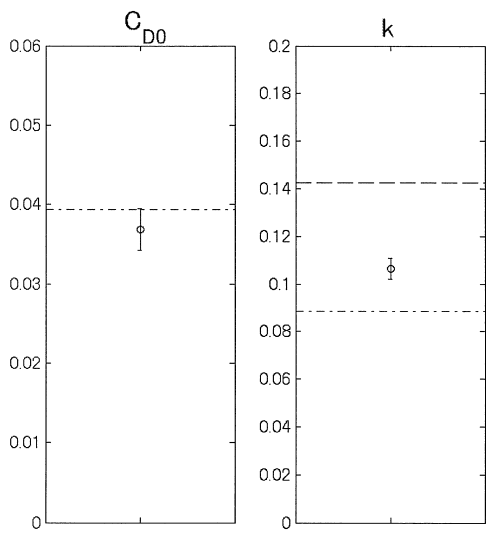

第 20 図 抵抗係数に関するパラメータ推定結果

一致を示しており，動的試験としての基本性能を実証して いるといえる .

一方, 空気力に関するパラメータについて，抵抗係数に 関しては比較的良い一致を示しているが，揚力係数と横力 係数に関して弚の推定值と参照値との間には大きな差が見 られる .これは解析に用いた空力モデルの準定常仮定によ るモデル化誤差の影響であると考えられる.第 22,23 図は 揚力係数とピッチングモーメント係数の迎角，無次元ピッ チング角速度との関係を回帰平面の縁から眺めた图である . データの回帰平面からの外れ方は加振周波数に応じて傾向 

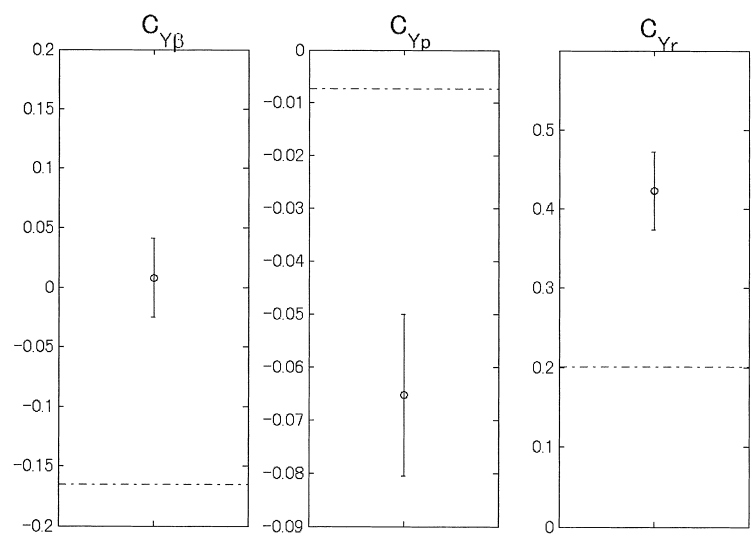

第 21 図 横力係数に関するパラメータ推定結果

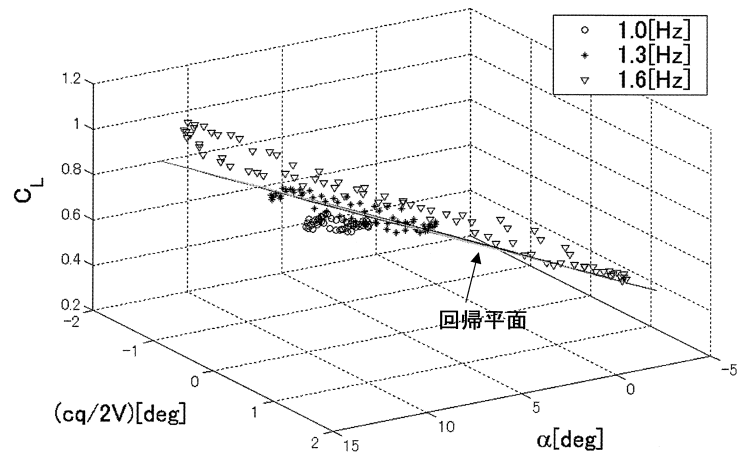

第 22 図 揚力係数に関する回帰平面

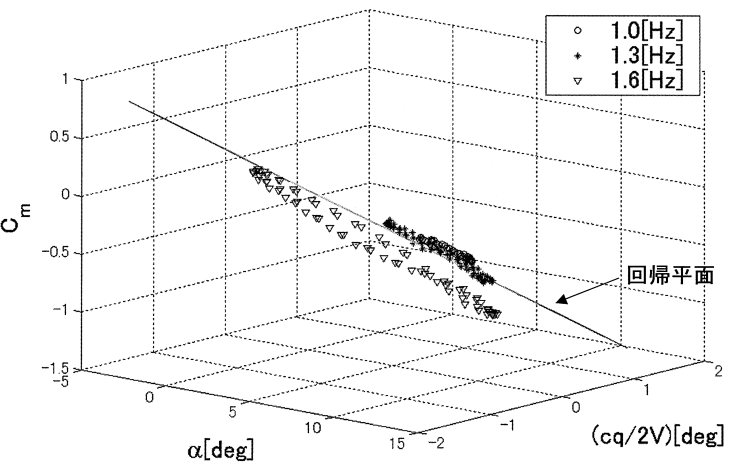

第 23 図 ピッチングモーメント係数に関する回帰平面

がある . ピッチングモーメント係数に関しては回帰平面の 傾きは変化していないが, 揚力係数に関しては平面の傾き か変化しており，空力微係数の值が周波数領域によって変 化していることがわかる . 速い応答特性をもつ小型無人機 の空力特性に関して光の周波数特性を含んだ飛行データを 本試験法によって得ることができると考えている．
6. 結 論

本稿では動的な空力特性を取得するための一手法として， 係留飛行による動的風洞試験を提案した．試験機体を機体 下部と左右翼端を 3 本のラインで垂直方向に拘束し, ライ ンを外部モータによって駆動するというものである .

まず，動的試験に際して係留飛行の安定性と固有運動に ついて考察し，係留飛行における迎角静安定条件と固有運 動の特性を把握した . 係留飛行において重心位置は迎角静 安定と無関係であり，張力中心が中正点よりも前方に位置 することか唯一の条件であり，重心が後方に位置する風洞 模型もこの点に注意して拘束すれば係留飛行が可能である ことを証明した . 係留飛行の固有運動は前後左右の振子運 動，係留点まわりの風見運動，機体軸まわりのローリング 運動, ライン方向の伸縮運動に分類される.一般に振子運 動の減衰は弱く，共振現象に注意を払う必要があるが，垂 直方向の係留飛行を行う場合, 振子運動の固有振動数は動 的試験での加振周波数よりも低いため，実際には問題には ならなかった 。

動的試験は縦試験と横試験の 2 つか実施され，加振周波 数を推移させながら運動を励起させることによって，自由 度の高い飛行データを取得することができた．準定常空力 モデルに基づく空力パラメータの推定結果は, 動特性に大 きく影響を及ぼすパラメータに関して推算值と良い一致を 示し，本試験法の基本性能を実証することができた .

今後は, 空気力の非定常性を含んだ空力モデルを用いて 空力特性の解析を行っていく予定である.

\section{参 考 文 献}

1) Shueler, C. J., Ward, L. K. and Hodapp, A. E., Jr.: Techniques for Measurement of Dynamic Stability Derivatives in Ground Facilities, AGARDograph, 121 (1967).

2) 谷一郎, 小橋安次郎, 佐藤 浩 : 流体力学実験法, 岩波書店, 東京, 1977, pp. 224-241.

3) Bennet, R. M., Farmer, M. G., Mohr, R. L. and Hall Jr. W. E.: Wind-Tunnel Technique for Determining Stability Derivatives from Cable-Mounted Models, J. Aircraft, 15 (1978), pp. 304-310.

4) Dynamic Wind Tunnel Test Group: Maximum-Likelihood Estimation of the NAL Spaceplane Aerodynamic Model Using Dynamic Wind Tunnel Tests, NAL TR-1307, 1996.

5) 小林 修: 飛行データからの空力特性推定法 (第 5 報) ガスト 及び炎の時間遅れの効果, 日本航空宇宙学会誌, 41 (1993), pp. $415-425$.

6) 東野伸一郎, 清水 哲, 野見山章, 桜井 晃: ドリフトを持つ角 速度センサを用いた RPRV の姿勢角の推定法について, 日本航 空宇宙学会誌, 45 (1997), pp. 713-718.

7）深見浩司，桜井 晃: 慣性モーメントの簡易的測定法, 日本航空 宇宙学会西部支部講演集, 2003, pp. 107-110.

8) USAF Stability and Control DATCOM: Flight Control Division, Air Force Flight Lab., Wright-Patterson Air Force Base, Ohio, 1975. 